\title{
CUSTOMER PREFERENCE TOWARDS COLD PRESSED OIL IN COIMBATORE CITY
}

\section{RAVEENDHAR ${ }^{1}$, T SAMSAI ${ }^{2}$ \& KMAHENDRAN ${ }^{3}$}

${ }^{1} P G$ Scholar, Department of agricultural and rural management, Tamil Nadu Agricultural University, Coimbatore, Tamil Nadu, India

${ }_{2}^{2}$ Assistant Professor, Department of agricultural and rural management, Tamil Nadu Agricultural University, Coimbatore, Tamil Nadu, India

${ }^{3}$ Professor, Department of agricultural and rural management, Tamil Nadu Agricultural University, Coimbatore, Tamil Nadu, India

ABSTRACT
The market for cold pressed oils has expanded significantly during several years in food industry, especially Tamil
Nadu. The investigation has attempted to recognize the variables impacting the preference of cold pressed oil and the
mindfulness about the advantages of these oils. Information has been gathered by appropriate survey method among
75 purchasers of cold pressed oils in Coimbatore city. The study investigation found that health benefits advantages of
cold squeezed oils exceptionally impact their preference, the respondents are profoundly mindful about the
unadulterated and natural form of cold pressed oils.
KEYWORDS: Cold Pressed oil, Factor influencing, Coimbatore city

Received: Dec 04, 2020; Accepted: Dec 24, 2020; Published: Jan 09, 2021; Paper Id.: IJESRDEC20205

\section{INTRODUCTION}

Cold pressed oil will be oil that holds its organic properties such as nutritive and therapeutic estimations of seed. In ancient period, all oils were cold pressed and hence it was constantly viewed as entirely significant food and had healthy properties. Cold pressed oil is initially produced in conventional manner by removing oil from seeds utilizing wood smasher, made of East Indian pecan tree which is squeezed with a substantial stone that is wheeled by bullocks. This kind of oil, squeezed in room temperature won't be warmed during the extraction cycle and holds the nutrition benefits and unique taste/flavour. There is no refining cycle needed for these oils. Our ancestors carried on with a long and sound life by utilizing this oil which gave them stamina, strength and resistance.

\section{Statement of the Problem}

Indian households using oil in daily basis for cooking as basic ingredient fragment. There were several branded refine oils dominated in market that are manufactured by chemical and mechanical process. Consumption of these refines oils result in cancer, diabetes and heart diseases. Hydrogenation process is involved in refined cooking oil which is very dangerous to human health. Customers in Tamil Nadu, particular in Coimbatore are shifted to cold pressed oil in cooking after knowing the harmful effect of refined oil. In this scenario, this study has taken the topic to identify factors influencing the customers to purchase the cold pressed oil. 


\section{Objective of the study}

To identify Factors Influencing the Customers to purchase the Cold Pressed Oil

\section{METHODOLOGY}

Coimbatore district was purposively selected to know the factor influencing the preference of cold pressed oil. Primary information was collected from the sample respondents who were came to purchase in specific organic store from five zone of Coimbatore city. From each zone 15 respondents were surveyed by using convenience sampling method and totally make a sample size of 75. Data were analysed with percentage analysis and Henry Garrett Ranking Technique. Percentage analysis were used examine the socio economic characteristics and problem faced by of sample respondents.

\section{Garrett's Ranking Technique}

Garrett's ranking techniques were used to help identify the factor influencing to purchase by sample respondents. The customer influenced factor were identified which will asked to rank by sample respondents. It was used to rank each factor and the rank was converted into per cent position by using the following formula.

$$
\text { Per cent position }=\underline{100 \times \sum(\mathrm{Rij}-0.5)}
$$

\section{$\mathrm{Nj}$}

Where,

Rij $=$ Ranking given for the $\mathrm{i}^{\text {th }}$ factor by the $\mathrm{j}^{\text {th }}$ respondents

$\mathrm{Nj}=$ Number of variable ranked by $\mathrm{j}^{\text {th }}$ respondents.

\section{RESULTS AND DISCUSSIONS}

The result and discussion of the study were presented under the following headings

- Demographic date of sample respondents.

- Customer preference towards cold pressed oil.

- Factor influencing the customers to purchase the cold pressed oil.

- $\quad$ Problem faced by sample respondents of cold pressed oil.

Table 1: Demographic Details of Sample Respondents

\begin{tabular}{|c|c|c|c|}
\hline \multirow{2}{*}{ CHARACTERISTICS } & CATEGORY & $\begin{array}{c}\text { NUMBER OF } \\
\text { SAMPLE } \\
\text { RESPONDENT } \\
\text { (n=75) }\end{array}$ & $\begin{array}{c}\text { PERCENTAGE } \\
\text { TO TOTAL }\end{array}$ \\
\hline \multirow{3}{*}{ Gender } & Male & 45 & 60 \\
\cline { 2 - 4 } & Female & 30 & 40 \\
\cline { 2 - 4 } & Total & 75 & 100 \\
\hline \multirow{3}{*}{ Age (In years)* } & up to 20 & 4 & 5.33 \\
\cline { 2 - 4 } & $21-30$ & 26 & 34.67 \\
\cline { 2 - 4 } & $31-40$ & 33 & 44 \\
\cline { 2 - 4 } & $41-50$ & 10 & 13.33 \\
\hline
\end{tabular}




\begin{tabular}{|c|c|c|c|}
\hline & $>50$ & 2 & 2.67 \\
\hline & Total & 75 & 100 \\
\hline \multirow{3}{*}{ Education } & Illiterate & 1 & 1.33 \\
\hline & Primary & 2 & 2.67 \\
\hline & Secondary & 11 & 14.67 \\
\hline \multirow{9}{*}{ Income( in Rupees) } & higher secondary & 7 & 9.33 \\
\hline & Graduate & 54 & 72 \\
\hline & Total & 75 & 100 \\
\hline & up to 20000 & 17 & 22.67 \\
\hline & $20001-30000$ & 17 & 22.67 \\
\hline & $30001-40000$ & 8 & 10.66 \\
\hline & $40001-50000$ & 24 & 32 \\
\hline & above 50000 & 9 & 12 \\
\hline & Total & 75 & 100 \\
\hline \multirow{4}{*}{ Family Size } & 1-2 members & 0 & 0 \\
\hline & 3-5 members & 33 & 44 \\
\hline & $>5$ members & 42 & 56 \\
\hline & Total & 75 & 100 \\
\hline
\end{tabular}

it could be inferred from the above Table1,that the respondents were classified based on different demographic features revealed that majority of sample respondent were male (60 per cent) followed by female ( 40 per cent). The most of sample respondents were come under the age category of 31-40 per cent followed by 44 per cent of the age category of 21 30 , nearly 2.67 per cent of the sample respondents were comes under the more than 50 age group category.

From the results, majority of sample respondent were graduate (72 per cent) and followed by secondary education (14.67 per cent). Most of the sample respondents were comes under the income category of 40001 to 50000 per month (32 per cent) followed by up to 20000 and 20001 to 30000 (22.67 per cent). Most of sample respondents were come under family member of above five of 56 per cent followed by three to five members per family of 44 per cent.

Since, majority of the sample respondents were educated, it is easy for all the cold pressed companies to communicate the product details and promotion and so on through pamphlets and other medias.

\section{Customer Preference towards Varieties of Cold Pressed Oil}

Customer preference varies from person to person. There were different sort of preference towards varieties of cold pressed oil by sample respondents. The results are presented in Table 2. 
Table 2: Customer preference towards Varieties of Cold Pressed Oil

\begin{tabular}{|l|l|l|l|}
\hline \multicolumn{1}{|c|}{ S. No } & \multicolumn{2}{|c|}{ Carieties of Oil } & \multicolumn{2}{c|}{ Cold Pressed Oil (n=75) } \\
\cline { 3 - 4 } & & No. of Sample Respondents & $\begin{array}{c}\text { No. of Varieties oil } \\
\text { Customer }\end{array}$ \\
\hline 1. & & & 43.03 \\
\hline 2. & & & 35.44 \\
\hline 3. & Groundnut oil & 68 & 21.51 \\
\hline
\end{tabular}

It could be inferred from table 2 that most of sample respondent prefer groundnut oil of 40.03 per cent followed by sesame oil (35.44 per cent) and coconut oil (21.51 per cent).

\section{Factors Influencing the Customers to purchase the Cold Pressed Oil}

The seven purchase influencing variables were analysed for their importance. The analysis revealed that the customer considers all the seven variables as important in his selection for purchase influence. The factors has been arranged based on their ranking as given in Table 2.1

Table 3: Purchase Influencing Factors for Factor Analysis (n=75)

\begin{tabular}{|l|l|l|l|}
\hline \multirow{2}{*}{ S.No } & \multicolumn{1}{|c|}{ Factors } & \multicolumn{2}{c|}{ Cold Pressed Oil (n=75) } \\
\cline { 3 - 4 } & \multicolumn{1}{|c|}{ Mean Score } & \multicolumn{1}{c|}{ Rank } \\
\hline 1. & Health conscious & 72.72 & 1 \\
\hline 2. & Quality & 69.24 & 2 \\
\hline 3. & Flavour and Taste & 55.12 & 3 \\
\hline 4. & Availability & 44.23 & 4 \\
\hline 5. & Package & 43.05 & 5 \\
\hline 6. & Price & 38.64 & 6 \\
\hline 7 & Brand & 38.85 & 7 \\
\hline
\end{tabular}

It could be concluded from the table 3 that, majority of the sample respondents were influenced by because of Health conscious (mean score 72.72) as it ranked first. The second important factor influenced by sample respondents were quality to purchase cold pressed oil with mean score of 69.24 followed by Flavour and taste (55.12 mean score). The fourth factor which influenced sample respondents to purchase cold pressed oil were Availability (44.23 mean score) followed by package (43.05 mean score), price (38.64 mean score) and brand (38.85 mean score).

\section{Problems faced by Sample Respondents of cold pressed oil}

Purchase of any product in market world will always be many problems. Likewise, in case of cold pressed oil products. Prelisted interview schedule of major identified problems were asked to mark by sample respondents. Percentage analysis 
was used to identify major problem and the results are presented in Table

Table 4: Problems faced by Sample Respondents while Purchasing Cold Pressed Oil Products

\begin{tabular}{|l|l|l|l|l|}
\hline \multicolumn{1}{|c|}{ S. No } & \multicolumn{1}{|c|}{ Problem } & \multicolumn{1}{|c|}{$\begin{array}{c}\text { No. of Sample } \\
\text { Respondents }\end{array}$} & $\begin{array}{c}\text { Total No. of } \\
\text { Sample } \\
\text { Respondents }\end{array}$ & $\begin{array}{c}\text { Percentage to total } \\
\text { No. of Sample } \\
\text { Respondents }\end{array}$ \\
\hline 1. & Non-availability & 32 & 75 & 42.67 \\
\hline 2. & Less number of branded product & 20 & 75 & 26.67 \\
\hline 3. & High cost & 62 & 75 & 82.67 \\
\hline 4. & Long distance travel to buy & 32 & 75 & 42.67 \\
\hline 5. & No quality assurance certification & 24 & 75 & 32 \\
\hline 6. & Impurities & 34 & 75 & 45.33 \\
\hline 7 & Packing & 50 & 75 & 66.67 \\
\hline
\end{tabular}

It could be inferred from table 4 that the 82 per cent problem faced by sample respondents while purchasing cold pressed oil were high cost followed by packing of cold pressed oil (66.67 per cent). 45.33 per cent of problem faced by sample respondents were impurities followed by non-availability (42.67 per cent), long distance travel to buy (42.67 per cent), no quality assurance certification (32 per cent) and less number of branded product (26.67 per cent).

\section{SUGGESTION AND CONCLUSIONS}

Based on survey and analysis, Health consciousness plays important role in factor influencing the sample respondents to purchase cold pressed oil. Now days customer were highly concentrate on their health so they searching towards health benefits of any product in which cold pressed oil is one among the healthy benefit product of edible oil. My study helps the marketer to concern about the purity of the oil which helps in holding nutritional value with health benefits and marketer should follow the business ethics. Customers' least influencing factors were price and brand because the cost of making one litre of pure cold pressed oil needs more raw materials. Brand of cold pressed oil does not play an important role in customer preference and it can be seen that a lot of unbranded cold pressed oil is available in the market and sample respondents prefer only them. There will be huge demand for cold pressed oil for next five years so marketer should be concern with quality and purity of oil with nil chemical ingredients.

\section{REFERENCES}

1. Costagli, G., \& Betti, M. (2015). Avocado oil extraction processes: method for cold-pressed high-quality edible oil production versus traditional production. Journal of Agricultural Engineering, 46(3), 115-122.

2. Revathy, B., \& Anitha, A. (2017). A Study on Consumer Preferences towards Edible Oil in Tirunelveli District. International Journal in Management \& Social Science, 5(12), 205-211.

3. Srilekha, J. 2018, A Study On Edible Oil Market With Special Reference To Cold Pressed Oil. International Conference on Emerging Trends in Management.5(4), 152-157. 

